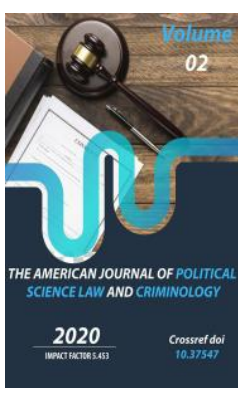

\title{
Non-Profit Organizations: Legislation Reform And Law Enforcement Practice
}

\author{
Anvar Akhrorkulov \\ Independent Researcher At Tashkent State University Of Law, Uzbekistan
}

Copyright: Original content from this work may be used under the terms of the creative commons attributes 4.0 licence.

\section{ABSTRACT}

Article deals with the current legislation on non-profit organizations, legal extent of activities of these organizations, wide involvement of non-profit organizations in civil affairs, issues of further improvement of law enforcement practice through the implementation of proposals on changes in the Civil Code of the Republic of Uzbekistan.

\section{KEYWORDS}

Action Strategy, "road map", non-profit organizations, dualistic, budgetary institutions, subsidiary liability, consumer cooperatives, government institutions, municipal institutions.

\section{INTRODUCTION}

Adoption of the Action Strategy has given a strong impetus to the development of all areas of socio-political and socio-economic development of the country. Action Strategy, in essence, has become a "road map" of reforms for the next five years, which will accelerate targeted development of our country and society.
Laws of the Republic of Uzbekistan "On Public Associations in the Republic of Uzbekistan", "On Non-Governmental Organizations", "On Political Parties", "On Public Funds", "On Guarantees of Activities of Non-Governmental Organizations" and a number of other presidential decrees, decisions and Government decisions were adopted. In 
general, more than 200 acts of legislation have been adopted to strengthen the legal status, role and importance of civil society institutions number of which is growing every year.

Within the framework of the Action Strategy, special attention was paid to further development of the "third sector" and provision of comprehensive assistance. Over the past period, reform of a number of civil society institutions took place. In order to effectively implement tasks, set out in the Action Strategy, government supported proposals of public organizations on establishment and revision of a number of new non-governmental non-profit organizations such as Independent Institute for Monitoring the Formation of Civil Society (ICRI), "Mahalla" Fund, "Nuroniy" Fund, Chamber of Commerce and Industry of Uzbekistan, Youth Movement of Uzbekistan, Council of Farmers, Dehkan Farms and Landowners of Uzbekistan, Development Strategy Center, "Ezgu Maksat" Fund, Culture and Arts Development Fund under the Ministry of Culture.

Today, international non-profit organizations are also active. In particular, international nongovernmental organization "Buyuk Klajak" passed state registration in the Ministry of Justice. It was reported that the organization has established an expert council with the participation of Uzbek nationals living and working abroad.

International non-profit organization "Buyuk Kelajak" is aimed to present new proposals for reforms in Uzbekistan. In particular, in the framework of the Action Strategy until 2021, it will work closely with the Development Strategy Center. At the same time, they will jointly submit proposals for government programs to be developed in the coming years by active involvement of members of council of experts in various fields. The main goal of the organization is to develop long-term proposals and strategies that will serve more rapid development of Uzbekistan.
Meanwhile, National Association of Electronic Mass Media of Uzbekistan should be noted as a large civil society institution uniting the efforts of 575 non-governmental non-profit organizations has greatly contributed to expanding the range of NGOs involved in the State Program.

Transition to market economy in our country has laid the foundation for radical changes in all spheres of life, as well as the need for a new approach to non-profit organizations' legal form as a special type of legal entity. Wide involvement of non-profit organizations in civil relations, performing mainly non-profit functions, is also an active participant in property relations, requires a new assessment of the legal status of these subjects of civil relations, as well as their property basis.

It should be noted that non-profit organizations as a separate organizationallegal form are relatively common types of legal entities and play an important role in ensuring interests of state and society. In this regard, the First President of the Republic of Uzbekistan I.A. Karimov noted that civil institutions, non-governmental non-profit organizations had become an important factor in protecting democratic values, human rights and freedoms and legitimate interests, helped to ensure a balance of interests in society and created conditions for increasing socioeconomic activity and legal culture [1].

Indeed, nonprofits can be organized both as state-owned and as NGOs. Therefore, it is important to define legal status of non-profit organizations as legal entities in property issues and their use in civil proceedings, and highlight general dualistic (two-sided) aspects that unite them as state-owned or nongovernmental organization.

In addition, diversity of types of non-profit organizations as legal entities, the fact that their participation in civil law relations is regulated by various laws is also of great relevance today. 
Regulations for property owning by non-profit organizations as a legal entity are set out in the Civil Code. However, the Code mainly regulates legal status of state-owned non-profit organizations and institutions, whereas there very limited rules related to legal capacity of non-profit organizations or their property. Therefore, it is expedient to expand the legal capacity of non-profit organizations in the Civil Code and general rules specific to this particular type.

Non-profit organizations (institutions) in many cases play an important role in the life of the state and society as a legal entity established by the owner and aimed at performing managing, socio-cultural functions or other non-commercial functions. While main purpose of them is non-profit, they can engage in entrepreneurial activities and thereby earn a certain income. Therefore, it is important to improve legal norms relating NGO's entrepreneurial activities.

Current legislation does not provide specific rules on the form of ownership of institutions. This, in turn, creates difficulties in recognizing a legal entity established and financed by the owner as an institution for the implementation of certain types of socio-cultural tasks and in determining its legal status. Therefore, it is necessary to stipulate in the legislation that institutions can be established by both public and private entities.

In the Civil Code, minimum amount of financial security and its terms are not specified, while NGOs are established by owners and are defined as an organization that is fully or partially funded.

Today, property liability of an NGO is regulated differently. It should be noted that there are cases when law enforcement and judicial practice collide with cases of extortion of funds from the institution. In this case, no recovery may be imposed on other property of the institution.
In this case, we should address the decision of the Plenum of the Supreme Arbitration Court of the Russian Federation No.21 dated June, 22, 2006 and Information Letter No.45 dated July 14, 1999, that explain order of imposition of foreclosure on the institution's property [2].

Limits of liability of budgetary institutions is determined by different categories of property, and its specificity is reflected in enforcement of recovery on their funds. Unlike civil liability of private and budgetary institutions, it does not provide for subsidiary liability of budgetary institutions. However, there is a similarity in the focus on cash recovery. Absence of subsidiary liability creates legal ambiguity in cases where creditors' claims do not exist or are insufficient for the debtor's property. Some researchers suggest changing the organizational and legal form of the institution as a solution to this[3]. However, other researchers note that such approach is controversial[4].

Existing provisions on the independent property liability of a public institution do not sufficiently satisfy the interests of creditors. In some cases, the creation of "beneficial institutions" seems like a fiction. Because the social orientation of the institution's activities deprives them of the opportunity to benefit.

All funds of institution are usually spent on the maintenance of its property. In addition, Civil Code prohibits recovery of property of special value. It follows that it is unlikely that there will neither any money left to satisfy creditors' claims, nor will there be any attractiveness of the remaining property or to the "special value" property.[5].

Article 28 of the Law of the Republic of Uzbekistan "On Non-Governmental Non-Profit Organizations" stipulates that a nongovernmental non-profit organization shall be liable for its obligations with property that may be recovered in accordance with the law. However, the question of what property of a non-profit organization falls into this category 
remains open. In this regard, the laws of the Russian Federation "On Nonprofit Organizations" and "On Autonomous Institutions"[6] sets specific requirements and such types of property are determined by public authority or administration. List of such property shall be determined by relevant bodies exercising functions and powers of the founder. Moreover, the "Procedure for recognizing property of an autonomous or budgetary institution as having special value", approved by the Government of the Russian Federation on July 26, 2010 No. 538[7] defines the following criteria:

1) if the value from 200 thousand to 500 thousand rubles for federal autonomous and budgetary institutions, from 50 thousand to 500 thousand rubles - for subjects of the Russian Federation, from 50 thousand to 200 thousand rubles - for municipal institutions;

2) other property, if its seizure leads to a situation in which NGO is unable to achieve its statutory purposes in accordance with the charter;

3) property, the alienation of which requires a special procedure in accordance with the legislation, including museum collections and objects, museum fund, archival fund documents, etc.

In accordance with Article 3 of the Law of the Republic of Uzbekistan "On Museums", a museum is a permanent non-profit cultural institution established by the owner for storage, study and public display of museum objects and museum collections. In this case, legislature includes museums in the list of nonprofit organizations in the organizational-legal form of institution.

As to Paragraph 19 of "Regulation on the order of organization, reorganization and liquidation of museums", approved by the Cabinet of Ministers of the Republic of Uzbekistan No.68 dated April 12, 2010, enrichment of the material and technical base of museums with necessary buildings, communications, equipment, museum objects and collections, other property used in their storage, identification, collection, implementation of cultural, educational, scientific and educational activities, study, publication and other tasks in the field of publishing.

In our opinion, it is not expedient to set such detailed criteria because in practice it is impossible to focus the collection on the property of the institution. At the same time, some institutions have such property that their alienation does not allow the institution to perform its functional functions. For example, vehicles, special equipment, devices, intellectual property, etc.

Although Paragraph 3 of Article 40 of the Civil Code of the Republic of Uzbekistan stipulates that a non-commercial legal entity may be established in the form of a public association, social fund or institution financed by the owner, in Chapter 3, dedicated to noncommercial organizations, Article 73 stands for consumer cooperatives, Article 74 - for public associations, Article 75 - for public funds. However, amendment to the Civil Code dated from April 30, 2004 is correctly expressed in separate articles, while part 3 of Article 40 remained without changes, i.e. in the form of social fund. This shortcoming has been overlooked and needs resolution.

At the same time, there are no special rules on the types of non-profit organizations and their organizational-legal form.

In this regard, it is necessary to determine general rules of non-profit organizations before determining their list and types in the Civil Code. This practice is used in legislation of a number of foreign countries. In particular, a separate paragraph of the Civil Code of the Russian Federation (Articles $123^{1}-123^{16}$ ) is devoted to non-profit organizations.

Chapter 4, Paragraph 3 of the Civil Code of the Republic of Uzbekistan should be added with Article $72^{1}$ as follows: 


\section{"Article $72^{1}$. General rules for non-profit organizations}

A non-profit organization is a legal entity that does not intend to make profit as the main purpose of its activities, does not distribute profits among the participants, the founder (participant) acquires the right to participate (membership) and forms supreme body of the organization.

Non-profit organization is organized in the form of a consumer cooperative, public association, public fund, institution, association of legal entities, citizens' selfgovernment body, Chamber of Advocates, company of private homeowners.

A non-profit organization is established by the decision of general meeting of founders, conferences, congresses, etc. These bodies approve the charter of the non-profit organization and form its bodies.

Non-profit organizations are the owners of their property.

The charter of a non-commercial organization may provide for the establishment of other legal entities, as well as participation in other legal entities, opening of branches and representative offices on the basis of the decision of the collegial body."

Provisions of the Civil Code relating to institutions are very abstract, and do not specify rules on the status of institutions.

In our view, such uncertainty makes it difficult in practice to determine the status of private institutions. For example, let's consider nongovernmental educational institutions which are widespread today. In order to fill this gap, it is necessary to add Articles $76^{1}, 76^{2}$ to the Civil Code and establish norms separately for public and private institutions. These rules should supposedly be expressed as follows:

“ Article 76' . State and municipal institutions
State or municipal institutions are established on the basis of the right of operational management.

The procedure for financing the activities of state or municipal institutions shall be established by law.

State or municipal institutions shall not be liable for the obligations of the owner of their property.

State or municipal institutions shall be liable for their obligations with the funds at their disposal. In case of insufficient funds, the owner of the property of the state or municipal institution shall be subsidiary liable for the obligations.

State or municipal institutions shall be liable for their obligations under all operational property rights, including proceeds from incomegenerating activities, movable property of special value attached to a state or municipal institution, including from what funds are accounted for. with the exception of real estate.

In case of insufficiency of the property of state or municipal institutions, which may be recovered in accordance with part 1 of this article, the owner of the property of the institution shall be subsidiary liable for the obligations arising as a result of damage to citizens.

In cases provided by law, state or municipal institutions may be reorganized in the form of a non-profit organization of another organizational and legal form.

The specifics of the legal status of state or municipal institutions are determined by law.

\section{Article $^{2}$. Private institutions}

A private institution is fully or partially funded by the owner of its property.

A private institution shall be liable for its obligations with the funds at its disposal. In case of insufficiency of the specified property, 
The American Journal of Political Science Law and Criminology (ISSN - 2693-0803)

Published: October 28, 2020 | Pages: 129-134

Doi: https://doi.org/10.37547/tajpslc/Volume02Issue10-20

the owner of its property is subsidiary liable for the obligations of the private institution.

A private institution may be reorganized in the form of a fund."

\section{REFERENCES}

1. Abdusalomov M. Civil-legal methods and problems of protection of entrepreneurs' rights and interests. Abstract. - T. : 2003. P.11

2. Civil rights. Book 1. Textbook. Ed. E.A.Sukhanov -M .: "BEK". 1998. -197 p.

3. Civil law. Part 1. M.: Prospekt. Ed. S.P.Sergeev, K.Tolstoi 1999. -127 p.

4. Zokirov I.B. Civil law of the Republic of Uzbekistan. -T .: Adolat, 1996 -57 p.

5. Team of authors. Comments on the Civil Code. T.1. T .: Vector press, 2010. 72-73 p.

6. Team of authors. Civil law. Textbook. Part 1. T.: TSUL, 2017. $81 \mathrm{p}$.

7. Ponamareva O.A. Legal regulation of the order of creation of non-commercial organizations. // Management. Issue №6 (37), December, 2015. -255 p.

8. Soyfer T.V. The concept of non- profit organizations in Russian civil law. Author's abstract of the dissertation for the degree of Doctor of Sciences. -M., 2010.

9. Yuldashev J. Joint-stock companies - as a subject of civil law. T.: TSIL, 2004. 128 p. 